\title{
Hubungan Asupan Protein, Kalsium, Phosfor, Dan Magnesium Dengan Kepadatan Tulang Pada Remaja Putri Di SMP Negeri 5 Padang
}

\author{
Noprisanti ${ }^{1}$, Masrul $^{2}$, Defrin $^{3}$
}

\begin{abstract}
Abstrak
Latar belakang Tulang merupakan organ keras dari semua jaringan dalam tubuh yang bersifat kuat dan kaku serta sulit dibengkokkan. Penurunan kepadatan tulang pada saat remaja dapat meningkatkan risiko terjadinya osteoporosis. Tujuan penelitian untuk mengetahui hubungan antara asupan protein, kalsium, phosfor, dan magnesium dengan kepadatan tulang pada remaja putri. Design penelitian, menggunakan cross sectional. Penelitian dilakukan di SMP Negeri 5 Padang pada bulan Maret sampai Mei 2018. Sampel penelitian ini 92 orang remaja putri yang berusia 13-15 tahun dengan teknik simple random sampling. Wawancara asupan protein, kalsium, phosfor, dan magnesium dengan menggunakan kuesioner modifikasi semi quantitative food frequency minang yang dirancang oleh lipoeto. Pengukuran kepadatan tulang dengan menggunakan alat bone densitometry metode quantitative ultrasound. Pengolahan data dilakukan menggunakan SPSS dengan analisis univariat, bivariat, dan multivariat. Hasil penelitian, rerata asupan protein $79,29 \pm 46,59$, kalsium $719,83 \pm 476,00$, phosfor $1493,71 \pm 914,89$, magnesium $335,33 \pm 197,13$, dan kepadatan tulang $-0,57 \pm 0,93$. Terdapat korelasi positif yang lemah dan tidak signifikan antara asupan protein dengan kepadatan tulang pada remaja putri $(r=0,034 ; p>0,05)$. Terdapat korelasi positif yang signifikan antara asupan kalsium, phosfor, dan magnesium dengan kepadatan tulang pada remaja putri $(r=0,294 ; p<0,05),(r=0,267 ; p<0,05)$, dan $(r=0,213 ; p<0,05)$. Kesimpulan, Asupan kalsium merupakan faktor yang dominan berhubungan dengan kepadatan tulang pada remaja putri.
\end{abstract}

Kata kunci: Asupan protein, kalsium, phosfor, magnesium, kepadatan tulang

\begin{abstract}
Background Bone is the organ of the hard of all tissues in the body which is strong and rigid and hard to bend. A decrease in bone density of adolescence can increase the risk of "Osteoporosis". The purpose of the study was to determine the relationship between the intake of protein, calcium,phosporus, and magnesium with bone density in adolescent girls. Design of Research: using Cross sectional approached. The research was conducted in Junior High School of Five (at SMP5) in Padang in March until May in 2018. The sample of the research was ninety two adolescent girls aged thirteen years old until fifteen years old with simple random sampling technique.Interview the intake of protein, calcium, phosporus, and magnesium by using questionnaire modified semi-quantitative food frequency minang designed by Lipoeto (a nutrionist). Measurement of bone density of the use of tools of bone densitometry methods as quantitative ultrasound. Data Processing was done by using SPSS with the analysis of Univariate, Bivariate, and Multivariate. The result: average protein intake $79,29 \pm 46,59$, calcium $719,83 \pm 476,00$, phosphorus $1493,71 \pm 914,89$, magnesium $335,33 \pm 197,13$, and bone density $-0,57 \pm 0,93$. There is a correlation positive weak and not significant correlation between protein intake of bone density of adolescents girls $(r=0,034 ; p>0.05)$. There is a significant positive correlation between the intake of calcium, phosphorus, and magnesium with bone density in adolescent girls $(r=0,294 ; p<0.05),(r=0,267 ; p<0.05)$, and $(r=0,213 ; p<0.05)$.
\end{abstract}

Keywords: Asupan protein, kalsium, phosfor, magnesium, kepadatan tulang

Affiliasi penulis : 1. Prodi S2 Kebidanan FK Unand 2. Bagian IImu Gizi FK Unand 3. Bagian Kebidanan FK Unand

Korespondensi : Noprisanti Email:novrisasushanty@gmail.com Telp: +6281393333326

\section{PENDAHULUAN}

Tulang adalah organ keras dari semua jaringan dalam tubuh yang bersifat kuat dan kaku serta sulit dibengkokkan. Tulang merupakan jaringan yang tersusun oleh sel dan matriks kolagen. Matriks kolagen dalam tulang manusia memiliki kandungan $65 \%$ material inorganik yang disebut matriks termineralisasi dan $35 \%$ material organik. Matriks termineralisasi ini sebagian besar mengandung kalsium dan posfor atau disebut juga kristal hidroksiapatit yang membuat struktur tulang keras. Penurunan kepadatan tulang dan perburukan mikro arsitektur tulang sehingga tulang menjadi rapuh dan mudah patah disebut dengan penyakit tulang osteoporosis. Selama ini osteoporosis identik dengan orang tua tapi faktanya pengeroposan tulang bisa menyerang siapa saja termasuk usia muda. ${ }^{1}$

Osteoporosis menjadi masalah kesehatan yang serius karena prevalensinya diseluruh dunia yang terus meningkat. Pada tahun 2050 di perkirakan 
kejadian patah tulang femur di dunia per tahun sebanyak 6,26 juta orang, sedangkan di Asia sebanyak 3,25 juta orang. Proses puncak perkembangan tulang terjadi sebelum umur 30 tahun,

\begin{tabular}{|c|c|c|c|c|c|c|}
\hline \multirow{3}{*}{ Variabel } & \multicolumn{6}{|c|}{$\begin{array}{c}\text { Kepadatan } \\
\text { Tulang }(n=92)\end{array}$} \\
\hline & \multicolumn{2}{|r|}{ Normal } & \multicolumn{2}{|c|}{ Osteopenia } & \multicolumn{2}{|c|}{ Osteoporosis } \\
\hline & & $f$ & $\mathrm{n}$ & $f$ & $\mathrm{n}$ & $f$ \\
\hline \multicolumn{7}{|l|}{ Asupan } \\
\hline Protein & & & & & & \\
\hline (g) & 22 & $24 \%$ & 10 & $10,9 \%$ & 1 & $1,1 \%$ \\
\hline Kurang & 13 & $14,1 \%$ & 8 & $8,7 \%$ & - & - \\
\hline Cukup & 25 & $27,1 \%$ & 13 & $14,1 \%$ & - & - \\
\hline \multicolumn{7}{|l|}{ Lebih } \\
\hline \multicolumn{7}{|l|}{ Asupan } \\
\hline \multicolumn{7}{|l|}{ Kalsium } \\
\hline (mg) & 49 & $53,3 \%$ & 31 & $33,7 \%$ & 1 & $1,1 \%$ \\
\hline Kurang & 3 & $3,2 \%$ & - & - & - & - \\
\hline Cukup & 8 & $8,7 \%$ & - & - & - & - \\
\hline \multicolumn{7}{|l|}{ Lebih } \\
\hline \multicolumn{7}{|l|}{ Asupan } \\
\hline \multicolumn{7}{|l|}{ Phosfor } \\
\hline (mg) & 22 & $24 \%$ & 19 & $20,6 \%$ & 1 & $1,1 \%$ \\
\hline Kurang & 5 & $5,4 \%$ & 2 & $2,2 \%$ & - & - \\
\hline Cukup & 32 & $34,8 \%$ & 11 & $11,9 \%$ & - & - \\
\hline \multicolumn{7}{|l|}{ Lebih } \\
\hline \multicolumn{7}{|l|}{$\begin{array}{l}\text { Asupan Mg } \\
\text { (mg) }\end{array}$} \\
\hline Kurang & 11 & $11,9 \%$ & 15 & $16,3 \%$ & - & - \\
\hline Cukup & 15 & $16,3 \%$ & 8 & $8,7 \%$ & 1 & $1,1 \%$ \\
\hline Lebih & 33 & $35,9 \%$ & 9 & $9,8 \%$ & - & - \\
\hline
\end{tabular}

setelah itu tidak dapat menambah kepadatan tulang secara signifikan. Sebesar $90 \%$ puncak pertumbuhan tulang terjadi pada umur 18 tahun untuk wanita dan 20 tahun untuk laki-laki, sehingga sebelum masa ini adalah masa terbaik untuk menginvestasikan kepadatan tulang. ${ }^{2}$

Sebanyak $41,8 \%$ laki-laki dan $90 \%$ perempuan sudah memiliki gejala osteoporosis. Hal ini menggambarkan bahwa proporsi osteoporosis lebih banyak pada wanita dan berdasarkan risikonya wanita lebih berisiko empat kali mengalami osteoporosis dibandingkan laki-laki. Tingginya kejadian osteoporosis pada wanita menyebabkan kondisi ini menjadi masalah kesehatan masyarakat. Khusus di kota Padang tahun 2013 dari 1105 orang yang diperiksa dengan alat densitometry diketahui $14,02 \%$ osteoporosis, $44,97 \%$ osteopenia dan $40,99 \%$ normal, artinya lebih tinggi prevalensi osteopenia yaitu terjadi penipisan pada tulang. Setiap orang memiliki risiko mengalami osteopenia dan berlanjut menjadi osteoporosis jika tidak dilakukan tindakan segera. ${ }^{3,4}$

Kepadatan massa tulang yang rendah dapat disebabkan karena beberapa hal seperti kekurangan protein, kalsium, posfor, dan magnesium. Komponen zat gizi lain seperti seng, zat besi, vitamin A, C, D, dan $\mathrm{K}$ diperlukan untuk metabolisme tulang secara normal. Ketidakseimbangan hormon estrogen pada wanita, gaya hidup (kebiasaan merokok, konsumsi alkohol, minuman berkarbonat, dan fast food), malabsorbsi, genetik, jenis kelamin, penggunaan jangka panjang dari kortikosteroid, serta pengaruh hormon (PTH, tirokalsitonin, growth hormon, dan tiroksin), serta jarang berolahraga atau kurang aktivitas dapat mempengaruhi kepadatan massa tulang. ${ }^{5}$
Berdasarkan studi pendahuluan di SMP Negeri 5 Padang pada bulan Februari 2018. Data yang diperoleh rata-rata pekerjaan orang tua siswi SMP Negeri 5 Padang adalah Buruh dan Pedagang Kecil dengan penghasilan dibawah satu juta per bulannya. Kegiatan belajar di SMP Negeri 5 Padang dimulai pukul 07.00 sampai 14.00 WIB. Kemudian dilakukan pemeriksaan kepadatan tulang siswi remaja putri SMP Negeri 5 Padang dengan menggunakan alat Bone Densitometry dengan memasukkan data umur dan jenis kelamin. Hasilnya dari 10 siswi remaja putri yang diperiksa kepadatan tulangnya 5 orang menunjukkan hasil kurang, dan 5 orang lagi menunjukkan hasil yang normal

Tujuan penelitian ini untuk mengetahui hubungan asupan protein, kalsium, posfor, dan magnesium dengan kepadatan tulang pada remaja putri di SMP Negeri 5 Padang.

\section{METODE}

Penelitian ini merupakan study potong lintang (cross sectional study). Variabel independen adalah asupan protein, kalsium, phosfor, dan magnesium. Variabel dependen adalah kepadatan tulang remaja putri.

Penelitian ini telah dilaksanakan pada bulan Maret sampai Mei 2018 di SMP Negeri 5 Padang. Teknik pengambilan sampel dilakukan dengan simple random sampling dengan total sampel 92 orang remaja putri. Kriteria inklusinya antara lain: Remaja putri berusia 13-15 tahun, mampu berkomunikasi dengan baik, dan tidak mengalami gangguan makan.

Kepadatan tulang diukur dengan menggunakan alat bone densitometry metode quantitative ultrasound (QUS). Data asupan protein, kalsium, phosfor, dan magnesium diperoleh melalui wawancara langsung dengan remaja putri menggunakan semi quantitative food frequency questionnaire (SQFFQ) modifikasi masakan minang yang dirancang lipoeto. Pengolahan data dilakukan dengan menggunakan SPSS dengan analisis univariat, bivariat, dan multivariat. ${ }^{6,7}$

\section{HASIL}

Syarat uji parametrik pearson adalah distribusi data normal dan varians data sama. Uji normalitas data menggunakan uji kolmogorov smirnov menunjukkan distribusi data tidak normal, sehingga dilakukan uji transformasi dengan menggunakan log10. Hasilnya menunjukkan distribusi data normal dengan nilai $p>0,05$. Distribusi frekuensi dan rerata asupan responden dapat dilihat pada tabel 1 dan 2 berikut ini: 
Tabel 1. Distribusi Frekuensi Asupan Protein, Kalsium, Phosfor, dan Magnesium dengan Kepadatan Tulang Pada Remaja Putri Usia 13-15 Tahun

\begin{tabular}{|c|c|c|c|c|c|c|}
\hline \multirow{3}{*}{ Variabel } & \multicolumn{6}{|c|}{ Kepadatan Tulang $(n=92)$} \\
\hline & \multicolumn{2}{|c|}{ Normal } & \multicolumn{2}{|c|}{ Osteopenia } & \multicolumn{2}{|c|}{ Osteoporosis } \\
\hline & $\mathbf{n}$ & f & $\mathbf{n}$ & $\mathbf{f}$ & $\mathbf{n}$ & $\mathbf{f}$ \\
\hline \multicolumn{7}{|c|}{ Asupan protein (g) } \\
\hline Kurang & 22 & $24 \%$ & 10 & $10,9 \%$ & 1 & $1,1 \%$ \\
\hline Cukup & 13 & $14,1 \%$ & 8 & $8,7 \%$ & - & - \\
\hline Lebih & 25 & $27,1 \%$ & 13 & $14,1 \%$ & - & - \\
\hline \multicolumn{7}{|c|}{ Asupan Kalsium (mg) } \\
\hline Kurang & 49 & $53,3 \%$ & 31 & $33,7 \%$ & 1 & $1,1 \%$ \\
\hline Cukup & 3 & $3,2 \%$ & - & - & - & - \\
\hline Lebih & 8 & $8,7 \%$ & - & - & - & - \\
\hline \multicolumn{7}{|c|}{ Asupan Fosfor (mg) } \\
\hline Kurang & 22 & $24 \%$ & 19 & $20,6 \%$ & 1 & $1,1 \%$ \\
\hline Cukup & 5 & $5,4 \%$ & 2 & $2,2 \%$ & - & - \\
\hline Lebih & 32 & $34,8 \%$ & 11 & $11,9 \%$ & - & - \\
\hline \multicolumn{7}{|c|}{ Asupan Magnesium (mg) } \\
\hline Kurang & 11 & $11,9 \%$ & 15 & $16,3 \%$ & - & - \\
\hline Cukup & 15 & $16,3 \%$ & 8 & $8,7 \%$ & 1 & $1,1 \%$ \\
\hline Lebih & 33 & $35,9 \%$ & 9 & $9,8 \%$ & - & - \\
\hline
\end{tabular}

Tabel 1 menunjukkan bahwa penelitian yang dilakukan pada 92 remaja putri di SMP Negeri 5 Padang. Subjek dengan kepadatan tulang normal lebih banyak $(64,1 \%)$, jika dibandingkan osteopenia $(34,8 \%)$ dan osteoporosis $(1,1 \%)$. Subjek dengan kepadatan tulang normal memiliki asupan protein lebih dari AKG sebanyak 25 orang, osteopenia 13 orang dan osteoporosis 1 orang dengan asupan protein kurang. Sedangkan Subjek dengan kepadatan tulang normal memiliki asupan kalsium kurang dari AKG sebanyak 49 orang, osteopenia 31 orang dan osteoporosis 1 orang. Pada subjek dengan kepadatan tulang normal memiliki asupan posfor kurang dari AKG sebanyak 22 orang, osteopenia 19 orang dan osteoporosis 1 orang. Sedangkan subjek dengan kepadatan tulang normal memiliki asupan magnesium lebih dari AKG sebanyak 33 orang, osteopenia 9 orang, dan osteoporosis 1 orang dengan asupan magnesium cukup.

Tabel 2. Rerata Asupan Protein, Kalsium, Posfor, Magnesium dan Kepadatan Tulang pada Remaja Putri Usia 13-15 Tahun

\begin{tabular}{llll}
\hline Variabel & Mean \pm SD & Min & Maks \\
\hline & & & 1,7 \\
$\begin{array}{l}\text { Kepadatan Tulang } \\
\text { (t-score) }\end{array}$ & $-0,57 \pm 0,93$ & $-3,5$ & 252,3 \\
Asupan Protein (gr) & $79,29 \pm 46,59$ & 21,60 & 3459, \\
Asupan Kalsium (mg) & $719,8 \pm 476,00$ & 177,1 & 0 \\
Asupan Posfor (mg) & $1493,71 \pm 914,8$ & 398,9 & 4940, \\
Asupan Magnesium & $335,33 \pm 197,13$ & 87,50 & 4 \\
(mg) & & & 1006, \\
& & & 7 \\
\hline
\end{tabular}

Hasil analisis didapatkan bahwa rerata kepadatan tulang remaja putri $-0,57 \pm 0,93$. Rerata asupan protein remaja putri $79,29 \pm 46,59$, asupan kalsium 719,83 $\pm 476,00$, asupan posfor

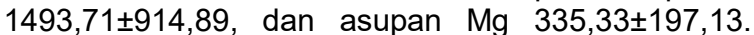
Asupan kalsium responden jauh di bawah nilai standar yang dianjurkan AKG untuk remaja putri usia 13-15 tahun yaitu $1200 \mathrm{mg}$.

\section{Hubungan Asupan Protein dengan Kepadatan Tulang pada remaja putri}

Berdasarkan gambar 1 dapat diketahui bahwa tidak terdapat hubungan yang bermakna antara asupan protein dengan kepadatan tulang remaja putri nilai $p=0,746(p>0,05)$. Analisis data menunjukkan bahwa arah hubungan positif artinya semakin tinggi asupan protein maka semakin tinggi nilai kepadatan tulangnya dimana kekuatan hubungan lemah nilai $r=0,034\left(R^{2}=0,001\right)$ artinya asupan protein hanya berkontribusi $1 \%$ terhadap kepadatan tulang.

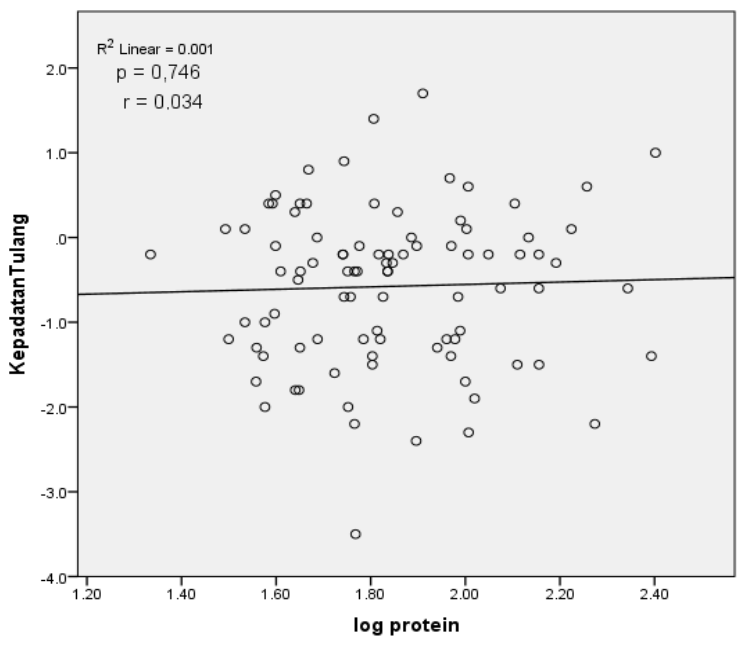

Gambar 1. Scater Plot Asupan Protein dengan Kepadatan Tulang

Hubungan Asupan Kalsium dengan Kepadatan Tulang pada remaja putri

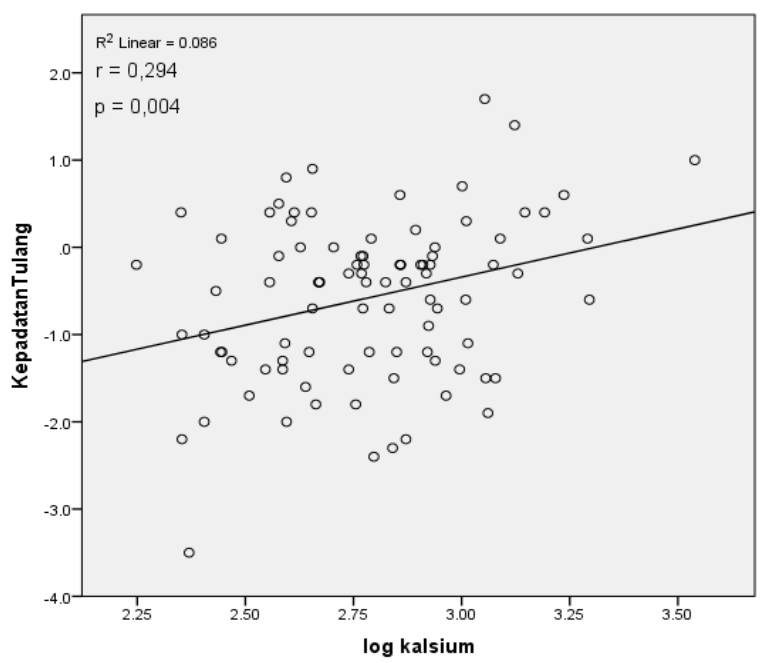

Gambar 2. Scater Plot Asupan Kalsium dengan Kepadatan Tulang

Berdasarkan gambar 2 dapat diketahui bahwa terdapat hubungan yang bermakna antara asupan kalsium dengan kepadatan tulang remaja putri nilai $p=0,004 \quad(p<0,05)$. Analisis data menunjukkan bahwa arah hubungan positif artinya semakin tinggi asupan kalsium maka semakin tinggi nilai kepadatan tulangnya dimana kekuatan hubungan lemah nilai $r=0,0294\left(R^{2}=0,086\right)$ artinya asupan kalsium hanya berkontribusi $8,6 \%$ terhadap kepadatan tulang. 
Hubungan Asupan Phosfor dengan Kepadatan Tulang pada remaja putri

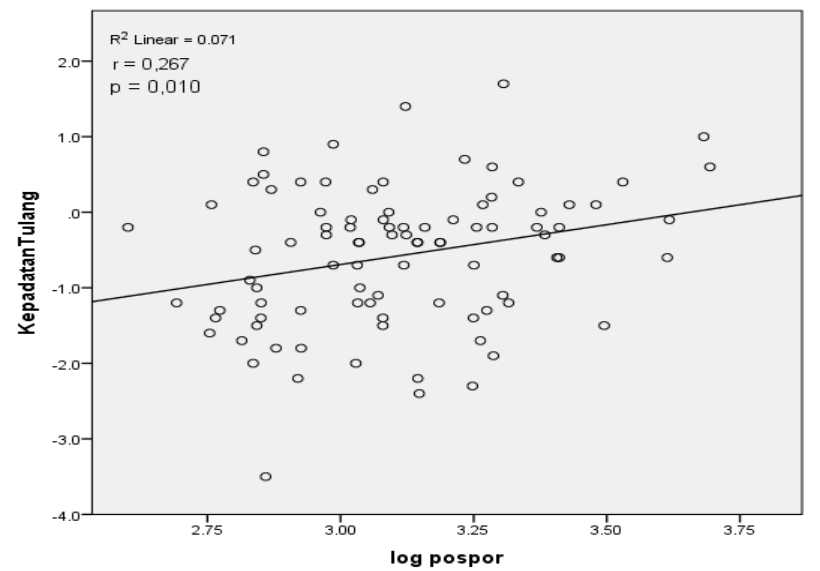

Gambar 3. Scater Plot Asupan Phosfor dengan Kepadatan Tulang

Berdasarkan gambar 3 dapat diketahui bahwa terdapat hubungan yang bermakna antara asupan posfor dengan kepadatan tulang remaja putri nilai $p=0,010(p<0,05)$. Analisis data menunjukkan bahwa arah hubungan positif artinya semakin tinggi asupan posfor maka semakin tinggi nilai kepadatan tulangnya dimana kekuatan hubungan lemah nilai $r=$ $0,0294\left(R^{2}=0,071\right)$ artinya asupan posfor hanya berkontribusi $7,1 \%$ terhadap kepadatan tulang.

Hubungan Asupan Magnesium dengan Kepadatan Tulang pada remaja putri

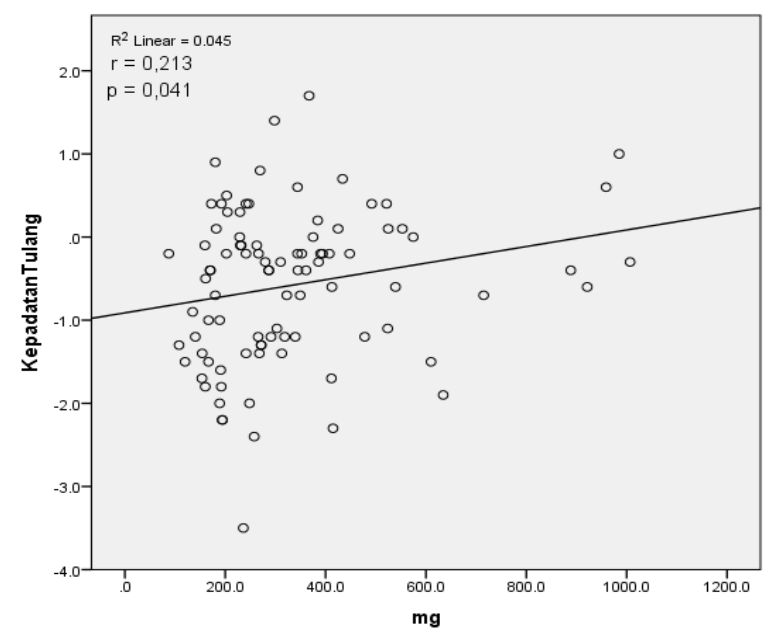

Gambar 4. Scater Plot Asupan Magnesium dengan Kepadatan Tulang

Berdasarkan gambar 4. dapat diketahui bahwa terdapat hubungan yang bermakna antara asupan $\mathrm{Mg}$ dengan kepadatan tulang remaja putri nilai $p=0,041(p<0,05)$. Analisis data menunjukkan bahwa arah hubungan positif artinya semakin tinggi asupan Mg maka semakin tinggi nilai kepadatan tulangnya dimana kekuatan hubungan lemah nilai $r=$ $0,0213\left(R^{2}=0,045\right)$ artinya asupan $M g$ hanya berkontribusi $4,5 \%$ terhadap kepadatan tulang.
Faktor yang Dominan Mempengaruhi Kepadatan Tulang pada Remaja Putri

Untuk mengetahui faktor yang dominan mempengaruhi kepadatan tulang pada remaja putri dilakukan analisis multivariat dengan menggunakan uji regresi linier ganda. Adapun variabel yang masuk dalam analisis tersebut adalah variabel yang mempunyai nilai $p<0,25$ pada uji bivariat. Hasil analisis dapat dilihat pada tabel 3 . dibawah ini.

Tabel 3. Hasil Analisis Multivariat Regresi Linier Ganda

\begin{tabular}{llll}
\hline Variabel & $\begin{array}{l}\mathbf{p} \\
\text { value }\end{array}$ & $\mathbf{r}$ & Persamaan \\
\hline $\begin{array}{l}\text { Asupan Kalsium } \\
\text { (mg/hari) }\end{array}$ & 0,004 & 0,294 & $\mathrm{Y}=0,294+0,086$ \\
\hline
\end{tabular}

\section{PEMBAHASAN}

Hasil penelitian ini didapatkan rerata kepadatan tulang responden $-0,57 \pm 0,93$. Sebagian besar remaja putri memiliki nilai kepadatan tulang normal yaitu $63 \%$, hal ini dikarenakan usia remaja merupakan usia dimana terjadi masa pembentukan tulang. Lebih dari $90 \%$ masa puncak kepadatan tulang terjadi pada usia 20 tahun dan terus berlanjut sampai umur 30 tahun. Sedangkan $35,8 \%$ remaja putri mengalami osteopenia dan $1 \%$ mengalami osteoporosis. Apabila keadaan ini tidak ditangani dengan baik maka dapat menyebabkan risiko terjadinya patah tulang dikemudian hari. ${ }^{2,7}$

Tulang adalah jaringan yang tersusun oleh sel dan matriks kolagen. Sel-sel yang menyusun tulang antara lain osteosit (sel tulang), osteoblas (sel pembangun), osteoklas (sel perombak) dan osteoprogenitor (sel tulang yang tidak mengalami pematangan). Sedangkan matriks kolagen dalam tulang manusia memiliki kandungan $65 \%$ material inorganik yang disebut matriks termineralisasi dan $35 \%$ material organik. Matriks termineralisasi ini sebagian besar mengandung kalsium dan posfor yang disebut juga kristal hidroksiapatit yang membuat struktur tulang keras. Sedangkan material organik sebagian besar terdiri dari fibrous protein yang disebut kolagen. Serat kolagen yang terhubung dengan jaringan tulang memberikan kekuatan dan fleksibilitas bagi tulang. Kepadatan tulang seseorang ditentukan oleh beberapa faktor seperti faktor genetik, faktor mekanik (aktivitas fisik dan berat badan), dan faktor zat gizi (protein, kalsium, posfor, dan Mg). Faktor genetik berperan sebanyak $70-75 \%$ terhadap massa mineral tulang, sedangkan faktor lingkungan seperti aktivitas fisik dan faktor nutrisi berperan hanya $25-30 \%$. ${ }^{7,8}$

Faktor yang dapat diubah yaitu nutrisi, diantaranya asupan protein, kalsium, posfor, dan Mg yang memadai dapat mengoptimalkan nilai kepadatan tulang. Asupan protein sangat penting bagi tulang dikarenakan sepertiga massa tulang dibentuk oleh protein dan akan terus mengalami perombakan. Banyak fragmen kolagen akan lepas selama proteoloysis saat proses remodeling dan tidak dapat digunakan kembali menjadi matrik tulang baru, sehingga manusia membutuhkan protein setiap harinya. Hasil penelitian ini didapatkan bahwa rerata asupan protein responden $79,29 \pm 46,59$, sebagian besar remaja putri memiliki asupan protein yang lebih 
yaitu sebesar $41,3 \%$. Asupan protein yang lebih tapi tidak diimbangi dengan asupan kalsium yang memadai akan meningkatkan risiko patah tulang. ${ }^{9}$

Kalsium merupakan mineral paling banyak terdapat dalam tubuh. Kalsium sangat penting untuk memaksimalkan pembentukan puncak massa tulang pada masa remaja. Penyerapan kalsium sangat bervariasi tergantung umur dan kondisi tubuh. Pada masa pertumbuhan sekitar $50-70 \%$ kalsium yang dicerna dapat diserap, kemampuan absorpsi lebih tinggi pada masa pertumbuhan dan menurun pada proses penuaan. Asupan kalsium remaja putri berada di bawah Angka Kecukupan Gizi (AKG) yang dianjurkan yaitu 1200 mg. ${ }^{9,10}$

Rerata asupan kalsium responden adalah $719,83 \pm 476,00$. Sebanyak $84,7 \%$ remaja putri mempunyai asupan kalsium kurang. Asupan kalsium subjek penelitian kurang karena rendahnya asupan makanan sumber kalsium. Sumber kalsium terutama terdapat pada susu dan hasil olahanya seperti keju, yogurt, ikan teri yang dimakan dengan tulangnya (teri, ikan, sarden), dan brokoli. Beberapa alas an subjek penelitian ini jarang minum susu karena takut gemuk, kurangnya pengetahuan tentang gizi, dan mahalnya harga susu.

Rerata asupan posfor responden adalah

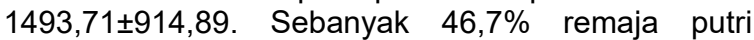
memiliki asupan yang lebih dari kebutuhan yang dianjurkan AKG. Asupan posfor berperan penting dalam pembentukan tulang. Kalsium dan posfor membentuk kristal hidroksiapatit yang akan mengeraskan tulang. Sekitar $85 \%$ posfor dalam tubuh disimpan dalam tulang, sedangkan 99\% kalsium ditemukan di tulang dalam bentuk kristal hidroksiapatit. Maka yang perlu diperhatikan bahwa kelebihan posfor secara nyata akan menurunkan kadar kalsium dalam darah. ${ }^{11}$

Rerata asupan Mg 335,33 $\pm 197,13$, sebanyak $54,3 \%$ remaja putri memiliki asupan yang lebih dari kebutuhan yang dianjurkan AKG. Asupan Mg memainkan peran penting pada metabolisme kalsium dan tulang dengan meningkatkan absorpsi kalsium. Mg juga berperan dalam mengubah vitamin D menjadi bentuk aktif yang dapat meningkatkan penyerapan kalsium. Apabila absorpsi kalsium dalam usus menurun maka hormon paratiroid akan meningkatkan reabsorpsi kalsium pada ginjal yang jika terus menerus terjadi dapat menyebabkan penurunan kepadatan tulang. ${ }^{17}$

\section{Hubungan Asupan Protein dengan Kepadatan Tulang Pada Remaja Putri}

Hasil penelitian ini menunjukkan bahwa asupan protein remaja putri $79,29 \pm 46,59$. Asupan protein merupakan salah satu zat gizi yang diperlukan dalam pencapaian kepadatan tulang dengan membantu menstimulasi pembentukan kolagen matriks tulang. Sepertiga massa tulang dibentuk oleh protein dan akan terus mengalami perombakan selama hidup. Kolagen yang lepas selama proteolysis saat proses remodeling tidak dapat digunakan kembali menjadi matrisk tulang baru, sehingga asupan protein yang cukup sangat diperlukan. Asupan protein yang rendah dapat mengakibatkan kepadatan tulang yang rendah. Akan tetapi, asupan tinggi protein juga mempunyai efek yang bertentangan dengan keseimbangan kalsium. ${ }^{12}$
Tidak adanya hubungan antara asupan protein dengan kepadatan tulang kemungkinan disebabkan karena faktor lain seperti asupan makanan (kalsium, vitamin D dan fosfor), faktor hormonal, dan aktivitas fisik yang berperan dalam meningkatkan kepadatan tulang. Protein bersifat amfoter (dapat beraksi dengan asam dan basa) sehingga berfungsi sebagai buffer untuk menjaga keseimbangan asam basa dalam tubuh. Ketika protein dari sumber hewani dikonsumsi secara berlebihan maka menyebabkan keadaan darah dalam tubuh menjadi lebih asam ( $\mathrm{pH}$ rendah). Protein hewani mengandung asam amino sistein dan metionin yang mengandung sulfur, sehingga untuk menetralkannya diperlukan kalsium bikarbonat yang bersifat basa. Apabila jumlah kalsium dalam darah tidak mencukupi, maka tubuh akan mengambil cadangan kalsium di tulang. Jika hal ini berlangsung dalam waktu yang lama maka kepadatan tulang akan menurun. ${ }^{13,14}$

Sebuah penelitian di Philadelpia menunjukkan asupan protein akan berhubungan signifikan dengan BMD apabila didukung dengan asupan kalsium (1000 mg per hari) dan posfor yang cukup. Pada penelitian ini, asupan protein dan posfor yang cukup tidak didukung dengan asupan kalsium yang memadai sehingga tidak mempengaruhi kepadatan tulang remaja putri. ${ }^{11,15}$

\section{Hubungan Asupan Kalsium dengan Kepadatan} Tulang Pada Remaja Putri

Hasil penelitian ini menunjukkan bahwa asupan kalsium remaja putri $719,83 \pm 476,00$, asupan kalsium remaja masih kurang dari angka kecukupan gizi yang dianjurkan AKG. Kebutuhan kalsium remaja putri umur 13-15 tahun $1200 \mathrm{mg} / \mathrm{hari}$. Hal ini kemungkinan dipengaruhi oleh rasio asupan kalsium dan posfor yang tidak seimbang. Kalsium berperan dalam mineralisasi tulang diperlukan untuk memaksimalkan puncak kepadatan tulang serta menjaga kepadatan tulang agar tetap normal. ${ }^{16}$

Apabila konsumsi kurang pada masa remaja yang terjadi cukup lama dapat mengakibatkan puncak kepadatan tulang tidak terbentuk secara optimal. Rata-rata konsumsi kalsium di Indonesia per hari hanya $245 \mathrm{mg}$ per hari dari 1200mg angka kecukupan gizi (AKG) kalsium yang dianjurkan tahun 2014. Asupan kalsium yang tidak adekuat memungkinkan pembentukan tulang yang tidak maksimal sehingga dapat menyebabkan osteoporosis. ${ }^{17}$

Kalsium adalah bahan utama pembentuk tulang yang disebut juga dengan hidroksiapatit yang berperan dalam mengeraskan tulang. Keseimbangan kalsium dalam tubuh dipengaruhi oleh kerja hormon diantaranya hormon paratiroid (PTH), kalsitonin, dan vitamin $\mathrm{D}$ atau kalsitriol. $\mathrm{PTH}$, kalsitonin. $\mathrm{PTH}$ memperngaruhi kalsium tubuh secara langsung melalui resorpsi tulang dan reabsorbsi kalsium pada tubulus proksimal da distal di ginjal. Pada usia remaja hingga dewasa hormon pertumbuhan dan hormon seks masih berfungsi aktif sehingga keseimbangan kalsium dalam darah masih terjaga. Homeostatis kalsium negatif disebabkan oleh kurangnya asupan makanan, gangguan absorpsi atau pengeluaran yang berlebihan yang mengakibatkan kehilangan kalsium dari tulang dan selanjutnya dapat meningkatkan kejadian patah tulang. ${ }^{17,18}$ 
Sejalan dengan penelitian sebelumnya yang menemukan ada hubungan bermakna antara asupan kalsium dengan tingkat densitas tulang remaja putri, dimana remaja putri dengan asupan kalsium kurang mempunyai peluang 52,7 kali memiliki tingkat densitas tulang abnormal dibanding asupan kalsium cukup. ${ }^{19}$

Hubungan Asupan Posfor dengan Kepadatan Tulang Pada Remaja Putri

Hasil penelitian ini menunjukkan bahwa asupan posfor remaja putri $1493,71 \pm 914,89$. Hasil penelitian ini sejalan dengan penelitian yang dilakukan pada remaja di Kota Padang yang menunjukkan adanya hubungan antara asupan posfor dengan kepadatan tulang $(p<0,05)$. Posfor bekerja bersama-sama dengan kalsium dalam memperkuat dan membentuk tulang dan gigi. Diet yang seimbang akan menjaga kecukupan jumlah posfor. Posfor bekerjasama dengan kalsium, maka yang perlu diperhatikan bahwa kelebihan posfor secara nyata akan menurunkan kadar kalsium dalam darah. ${ }^{12}$

Hasil penelitian ini berbeda dengan penelitian sebelumnya bahwa tidak ada hubungan yang signifikan asupan posfor dengan kepadatan tulang $(p>0,05)$. Posfor adalah mineral kedua terbanyak kedua setelah kalsium yaitu $1 \%$ berat badan. $85 \%$ posfor didalam tubuh bersama-sama dengan kalsium berada dalam rangka dan gigi dalam bentuk kalsium fosfat bagian dari kristal hidroksiapatit yang tidak dapat larut yang memberi kekuatan dan kekakuan pada tulang yang berperan sebagai struktural. Kegunaan utama posfor adalah mendukung pertumbuhan dan pergantian tulang yang hilang. Perbandingan yang tidak seimbang antara posfor dan kalsium dapat menghambat penyerapan kalsium sehingga dapat menimbulkan defisiensi kalsium. ${ }^{19}$

Meskipun posfor merupakan zat gizi penting, tetapi konsumsi yang berlebih dapat merugikan tulang. Posfor di dalam tulang berada dalam perbandingan 1;2 dengan kalsium. Rasio posfor yang tinggi terhadap kalsium dalam makanan dapat menurunkan absorpsi kalsium karena pembentukan garam kalsium oksalat yang tidak larut air. Selain itu, kombinasi asupan posfor tinggi dan asupan kalsium rendah dapat meningkatkan konsentrasi hormon paratiroid dan resorpsi tulang meningkat. ${ }^{24}$

\section{Hubungan Asupan Magnesium dengan Kepadatan Tulang Pada Remaja Putri}

Hasil penelitian ini menunjukkan bahwa asupan kalsium remaja putri $335,33 \pm 197,13$. Hasil penelitian ini sejalan dengan penelitian yang dilakukan pada remaja di Kota Padang yang menunjukkan adanya hubungan antara asupan magnesium dengan kepadatan tulang $(p<0,05)$. Magnesium adalah mineral utama yang perlu dikonsumsi lebih dari 100 miligram per hari. Sekitar $60-65 \%$ dari semua magnesium bertempat di tulang dan gigi. Sedangkan untuk sisanya $35-40 \%$ ditemukan di seluruh tubuh, termasuk otot, sel-sel jaringan, dan cairan tubuh. ${ }^{22}$

Hasil penelitian ini berbeda dengan penelitian sebelumnya bahwa tidak ada hubungan yang signifikan asupan magnesium dengan kepadatan tulang. Magnesium memainkan peran penting pada metabolisme kalsium dan tulang dengan meningkatkan absorpsi kalsium. Sehingga berdampak apabila asupan kalsium defisit memungkinkan terjadinya defisiensi magnesium. Bila asupan kalsium rendah, maka absorpsi magnesium meningkat. $\mathrm{Di}$ dalam darah sebagian besar magnesium terdapat dalam bentuk ion bebas, atau dalam bentuk molekul kompleks hingga molekul kecil. Keseimbangan magnesium melalui urin, ekskresi magnesium meningkat oleh hormon tiroid, asidosis, aldosteron serta kekurangan posfor dan kalsium. Ekskresi magnesium menurun karena pengaruh kalsitonin, glucagon dan PTH terhadap resorpsi tubulus ginjal. ${ }^{22,23}$

Bioavailabilitas magnesium dapat dipengaruhi oleh zat gizi lainnya. Pola makan tinggi serat yang berasal dari buah-buahan, sayuran, dan padi-padian akan mengurangi absorbsi magnesium fraksional. Tidak hanya itu, asam fitat dapat mengurangi absorbsi magnesium karena berikatan dengan Mg pada gugus fosfatnya. Diet tinggi fosfat mampu mengurangi absorbsi magnesium. Protein dapat mempengaruhi absorbsi magnesium intestinal. Absorbsi magnesium rendah saat asupan protein kurang dari $30 \mathrm{gr}$ perhari. Kekurangan vitamin B6 yang terjadi pada wanita akan berpengaruh pada keseimbangan magnesium karena akan meningkatkan sekresinya melalui urin. ${ }^{22}$

Faktor yang Paling Dominan Mempengaruhi Kepadatan Tulang Pada Remaja Putri

Hasil penelitian ini menunjukkan bahwa variabel asupan kalsium merupakan variabel dominan yang berhubungan dengan kepadatan tulang pada remaja putri, dengan nilai $p=0,004$ dan nilai $r=$ 0,294 . Persamaan regresi yang diperoleh nilai $Y=0,294+0,086$. Tulang adalah jaringan hidup dengan matriks protein kolagen yang telah diresapi oleh garam-garam mineral. Tulang menyokong tubuh dan memegang peranan penting pada homeostatis mineral, khususnya fosfat dan kalsium. Protein dalam serabut-serabut kolagen yang membentuk matriks tulang adalah kompleks. Jumlah yang adekuat dari protein dan mineral keduanya harus tersedia untuk mempertahankan struktur tulang yang normal. ${ }^{1,20}$

Kalsium merupakan mineral terbanyak di dalam tubuh $(1,5-2 \%$ dr BB org dws atau $\pm 1 \mathrm{~kg})$. Dari jumlah ini, $99 \%$ berada di dalam jaringan keras (tulang dan gigi) terutama dalam bentuk hidroksiapatit. Densitas tulang berbeda menurut umur. Meningkat pada bagian pertama kehidupan, dan berangsur menurun setelah dewasa. Dalam keadaan normal, $30-50 \% \mathrm{Ca}$ yang dikonsumsi diabsorpsi tubuh. Kemampuan absorpsi lebih tinggi pada masa pertumbuhan, dan menurun pada proses menua. Absorpsi Ca terutama terjadi di duodenum, dilakukan secara aktif dengan alat angkut protein pengikat kalsium. Sedangkan absorpsi pasif terjadi di permukaan saluran cerna $\mathrm{Ca}$ yang tidak diabsorpsi dan dikeluarkan melalui feses. Jumlah $\mathrm{Ca}$ yang dieksresi melalui urin mencerminkan jumlah $\mathrm{Ca}$ yg di absorpsi. ${ }^{24}$

Kebutuhan kalsium harus dipenuhi dari asupan makanan karena kalsium pada makanan diserap pada usus halus dengan proses transport aktif. Faktor yang membantu penyerapan kalsium adalah Vitamin D3 (kalsitriol), hormon-hormon (paratiroid, hormon pertumbuhan, kalsitonin), $\mathrm{pH}$ 
yang asam, diet tinggi protein dan banyak laktosa. Sedangkan faktor-faktor yang menghambat penyerapan kalsium adalah $\mathrm{pH}$ yang alkalis, gangguan absorpsi lemak, dan adanya pitat, fosfat, dan oksalat. Penyerapan kalsium dari lumen usus lalu diteruskan ke saluran darah, diangkut oleh protein yang terdapat didalam usus. Dari saluran darah kalsium disebarkan ke seluruh jaringan tubuh seperti tulang. ${ }^{20,24}$

\section{SIMPULAN}

Terdapat korelasi positif yang signifikan antara asupan kalsium, phosfor, dan magnesium dengan kepadatan tulang pada remaja putri $(r=0,294$; $p<0,05), \quad(r=0,267 ; p<0,05)$, dan $(r=0,213 ; p<0,05)$. Asupan kalsium merupakan faktor yang dominan berhubungan dengan kepadatan tulang pada remaja putri.

\section{SARAN}

Dianjurkan kepada remaja putri berusia 13-15 tahun untuk meningkatkan asupan kalsium sesuai dengan AKG yaitu 1200 mg/hari untuk mencegah terjadinya osteoporosis yang mana sudah dialami oleh remaja putri. Dianjurkan untuk mengkonsumsi kalsium yang banyak terdapat pada susu dan olahannya. Minum susu pada malam hari karena aktifitas tubuh kosong sehingga tubuh dapat menyerap secara optimal. Dibutuhkan penelitian lebih lanjut tentang faktor yang mempengaruhi kepadatan tulang terutama faktor genetik yang berkontribusi 70 $75 \%$.

\section{UCAPAN TERIMA KASIH}

Terima kasih kepada semua pihak atas bimbingan, arahan, saran dan motivasi dalam penelitian ini serta semua pihak lainnya yang telah memberikan kontribusi dalam pelaksanaan penelitian ini.

\section{DAFTAR PUSTAKA}

1. Sherwood L. Fisiologi Manusia dari Sel ke sistem. Jakarta : EGC; 2011.P.473-79.

2. Kemenkes RI. Data Kondisi Penyakit Osteoporosis di Indonesia. Infodatin Pusat Data dan Informasi Kementerian Kesehatan RI. Jakarta: Kemenrerian Kesehatan RI; 2015. p.18.

3. Kemenkes RI. Profil Kesehatan Indonesian Tahun 2016. Jakarta: Kementerian Kesehatan Republik Indonesia; 2017. p.133-37.

4. Badan Penelitian dan Pengembangan Kesehatan. Riset Kesehatan Dasar. Jakarta: Kementrian Kesehatan RI; 2013. 526-29.

5. Gibney MJ. Gizi Kesehatan Mayarakat. Jakarta: EGC; 2009. p.476-79.

6. Sastroasmoro S, Ismael S. Dasar-Dasar Metodologi Penelitian Klinis Edisi 4. Jakarta: Sagung Seto; 2014. p.51-54.

7. Helmizar, Jalal F, Lipoeto NI. Antioksidan Dalam Masakan Minang dan Potensi Protektif Terhadap Risiko Penyakit Kardiovaskuler. Jurnal Kesehatan Masyarakat. 2010: 4(1):13-19.

8. Setiyohadi B. Struktur dan Metabolisme Tulang. Buku Ajar IImu Penyakit Dalam. Edisi ke-4. Jakarta: Pusat Penerbitan IImu Penyakit Dalam Fakultas Kedokteran Universitas Indonesia; 2010. p.1096-106.
9. Setyawati B, Prihatini S, Rochmah W, Pangastuti R. Hubungan Indeks Massa Tubuh dengan Densitas Mineral Tulang Pada Perempuan Dewasa Muda (Association Between Body Mass Index and Bone Mineral Density in Young Adult Female). PGM. 2014; 34(2):93-103.

10. Wiarto G. Fisiologi dan Olahraga. Yogyakarta: Graha IImu; 2013. p.212-23.

11. Anderson JJB. Nutrition And Bone Health. In: Mahan K, Escott-Stump S, Editors. Krause's Food, Nutrition And Diet Theraphy. 12th Edition. Philadelphia: Saunders; 2012. p.614-33.

12. Faizah LN, Fitranti DY. Hubungan Asupan Protein, Fosfor, dan Kalsium dengan Kepadatan Tulang Pada Wanita Dewasa Awal. Journal of Nutrition College. 2015; 4(1):1-14

13. Nafilah, Fitranti DY. Hubungan Indeks Massa Tubuh (Imt), Persen Lemak Tubuh, Asupan Zat Gizi, Dan Aktivitas Fisik Dengan Kepadatan Tulang Pada Remaja Putri. Program Studi IImu Gizi Fakultas Kedokteran Universitas Diponegoro: Journal of Nutrition College. 2014; 3(4):680-88.

14. Lanham-New SA, Macdonald IA, Roche HM, editor. Metabolisme Zat Gizi. Jakarta: EGC; 2015. p.208-15.

15. Tucker KL, Rosen CJ. Prevention and Management of Osteoporosis. Modern Nutrition in Health and Disease. $11^{\text {th }}$ ed. Philadelphia: Lippincott William Wilkins; 2012. p.1227-238.

16. Ruseno JC, Rahayuningsih MH. Status Kepadatan Tulang Berdasarkan Kategori Lingkar Pinggang Wanita Dewasa. Journal of Nutrition College. 2015; 4(2):350-57.

17. Desrida, Afriwardi, Kadri $\mathrm{H}$. Hubungan Tingkat Aktivitas Fisik, Jumlah Asupan Vitamin D dan Kalsium Terhadap Tingkat Densitas Tulang Remaja Putri di SMA Negeri Kecamatan Tilatang Kamang Kabupaten Agam. Jurnal Kesehatan Andalas. 2017; 6(3):572-80.

18. Rahmawati AY. Hubungan Antara Indeks Massa Tubuh (IMT), Asupan Zat Gizi dan Riwayat Reproduksi Dengan Kepadatan Mineral Tulang Pada Wanita Pre Menopause. Jurnal Riset Kesehatan. 2016; 5(2):83-91.

19. Ramayulis R, Pramantara ID, Pangastuti R. Asupan Vitamin, Mineral, Rasio Asupan Kalsium dan Fosfor dan Hubungannya dengan Kepadatan Mineral Tulang Kalkaneus Wanita. Jurnal Gizi Klinik Indonesia. 2011; 7(3):115-122.

20. Guyton AC, Hall JE. Buku Ajar Fisiologi Kedokteran. Edisi 12. EGC: Jakarta: EGC; 2014. 1033-045.

21. Devi CS. Faktor Determinan Kepadatan Tulang Pada Mahasiswa FKIK UIN Syarif Hidayatullah. [Skripsi]. Jakarta: Fakultas Kedokteran dan IImu Kesehatan Universitas Islam Negeri Syarif Hidayatullah; 2017. p.66-68.

22. Syahrial, Vitria, Aini F. Hubungan Asupan Makanan dengan Massa Tulang Pada Anak SMA di Kota Padang. Padang: Fakultas Kesehatan Masyarakat Universitas Andalas Padang; 2012. p.1-12.

23. Kelsey MM, Shivani S, Jane EK. Dietary Protein is Beneficial to bone health under condition of adequate calcium intake: an update on clinical research. Curr Opin Cin Nutr Metab Care. 2014; 17(1):69-74. 
24. Maispaitella ML, Dieny FF. Hubungan Asupan Kalsium dan Fosfor, Indeks Massa Tubuh, Persen Lemak, Tubuh Kebiasaan Olahraga, Usia Awal Menstruasi dengan Kepadatan Tulang Pada Remaja Putri. Journal of Nutrition College. 2012; 1(1):229-40. 